\title{
THE ANALYSIS OF ROLE PLAY AND FEMALE LABOR SUPPLY IN RICE FARMING
}

\author{
Mulyana Eka*, Fitri, Zahri Imron, Damayanthy Dini \\ Study Program of Agribusiness, Faculty of Agriculture, University of Sriwijaya, Indonesia \\ *E-mail: eka.agri@gmail.com
}

\begin{abstract}
The number of population in Indonesia keeps increasing by 1.33 percent per year. The population growth in Indonesia affects the increased demand of national food needs, one of which is rice. Much efforts have been done to increase the production and productivity of rice farming, such as by improving the efficiency of involving female labors in performing rice farming. One of the reasons is women tend to be more patient and can have control in decision making. This research aims at: (1) analyzing and describing the role of female labors in rice farming and (2) analyzing the labor supply of rice farming. The data processing method is a descriptive statistical processing method. This research is conducted in Pegayut Village, Ogan Ilir Region and involves 30 female labors as samples. The result of the research shows that female labors have a role play in every stage of rice farming, especially during planting and cultivation stages. In line with this, it can be concluded that the biggest labor supply of female farmers is during the planting and cultivation stages.
\end{abstract}

\section{KEY WORDS}

Female labors, labor supply, rice farming.

Since Indonesia held its first population census in 1961, the population keeps increasing every year. BPS (Central Bureau of Statistics) records that there were at least 267 million of Indonesia's population in 2019. Data shows that over the past nine years (20102019), there has been an increase in population by 29,37 million and a growth rate of 1,33 percent per year (BPS, 2019). The rapid population growth in Indonesia has resulted in a high demand of food which also continues to increase, especially the main staple food of Indonesian people, namely rice (Khairati \& Syahni, 2016). Not only in Indonesia but also all over the world, especially developing countries which have tropical climate, rice is the main staple for nearly half population of people in the world (Hossain \& Narciso, 2004; Fairhurst \& Dobermann, 2002; Bantacut, 2014 in Wardani, et al. 2019).

Rice is known as a staple food which has high nutrients such as carbohydrates, protein, vitamins, and minerals (Verma \& Srivastav, 2020). Almost all Indonesians eat rice every day (Rohman \& Maharani, 2017). In 2010-2014, it is recorded that around 95\% of Indonesians eat rice with an average consumption of $87,32 \mathrm{~kg} /$ capita/year (Sulistyo, et al. 2016). The dependence of Indonesian people on rice keeps increasing every year. The Central Bureau of Statistics shows that in 2017 there was an increase of 3\% or as much as $98 \%$ of the population in Indonesia who consumed rice with an average consumption of $89,06 \mathrm{Kg} / \mathrm{capita} / \mathrm{year}$. Indonesia itself ranks third after China and India as one of the countries with the most rice consumption in the world (Statistia, 2019). The high demand of rice in Indonesia and several countries has become an opportunity for farmers. However, to get this opportunity, it needs an effective and efficient rice farming management.

Husodo (2017) states that the average indonesian farmer only owns and manages 0,036 hectare of agricultural land. Unlike farmers in developed countries such as in America, every farmer owns and manages at least 200 hectares of agricultural land (Pakpahan, 2018). This is why farming management including rice as the main commodity in Indonesia is still managed using a family farming system. In some literature related to developing countries, the term family farming is often referred to as smallholder farms (Garner \& Campos, 2014). The usage of that term is closely related to the size of the land owned by the farmers. Berdegué and Fuentealba (2011) considered that the term family farming or smallholders often used for perpetrators of farming with land owned by a maximum of 2 hectares. In 
addition, according to Liu (2012) in Han (2017), the term family farming can be used by farming actors with a maximum land area of $100 \mathrm{mu}$ or around 6,6 hectares. Family farming or a farming system is managed by one family and mostly depends on family labors such as women, men and children (Garner \& Campos, 2014).

Endang et al., (2014) in her research states that farming management using the family farming system is one of the solutions to improve farm family labor's efficiency to achieve better farming productivity. The improvement of farm family labor can be done in several ways, one of the ways is to involve family members and non-female family members in the farming management process. According to research done by farming first dan Food and Agriculture Organization, around $43 \%$ of the agricultural workforces in various developing countries are female (Committee on World Food Security, 2016). In Indonesia especially in Pegayut Village, Ogan llir District is one of the villages which involves female labors in the farming management process. This happens because females are patient when working. Unfortunately, for important things, female labors are rarely involved in some activities, for example, in the learning process of farming and decision making. The role of female labors in managing farming management seems invisible and is overshadowed by male workers. From the description of the problem above, the researchers are interested in conducting a study on the role and outpouring of female labors.

\section{METHODS OF RESEARCH}

This research was conducted in Pegayut Village, Pemulutan District, Ogan llir Regency, Sumatera Selatan Province. The location selection was carried out purposely by considering that in Pegayut Village, women are commonly involved in rice farming and this village has a large rice field area with a total of 239 hectares. Data collection was carried out at the research location in February - March 2020.

This research used a survey method which was done by taking samples from the population of farmers wives. From the survey method, it is expected that the information in the reality can be carried out by making question lists (questionnaire), taking samples, and collecting data by conducting an interview. Sample in this research was a woman (farmer's wife) who works on rice farming. The sample used in the research was 30 people from a total of 203 population of farmer wives in Pegayut Village. The method in taking examples used in the research was simple random sampling, in which the samples were taken randomly using a sweepstake method.

Data which were collected in this research are the primary and the secondary data. The primary data collection was obtained from interviews with the farmers as samples based on a questionnaire which has been prepared before. The secondary data which are useful to complement this research were obtained from institutions related to this research, namely the office of the village head of Pegayut, Pemulutan District as well as journals, books, articles, and previous research.

The role of female labors in rice farming will be analyzed using a descriptive statistical method. While the female labor supply in rice farming will be analyzed by the following formula (Ridwan, et al, 2019):

$$
\mathrm{TK}=\frac{J K \times J H K}{I S T}
$$

Where: TK Supply = The Labor Supply of Female Farmers in Every Farming Activities (HOK); JK = Female Farmers Working Hours (Hours/Day); JHK = The Number of Female Farmers Working Days (Day); JST = Hour Unit (8 hours).

\section{RESULTS AND DISCUSSION}

This research was conducted on 30 samples of female farmers who were selected randomly. The characteristics of the samples used in this research consist of several 
variables, such as age, education background, farming experience, the number of family dependents, and land area. All of the variables are explained using descriptive statistical methods (percentage, mean, and standard deviation). For more details, data related to the characteristics of respondents can be seen in Table 1 below:

Table 1 - The Characteristics of the Sample

\begin{tabular}{lllll}
\hline Variables & Categories & Percentage & Mean & SD \\
\hline \multirow{2}{*}{ Age (Year) } & $31-40$ & 23.3 & 36.5 & 2.7 \\
& $41-50$ & 53.3 & 45.2 & 3.3 \\
& $51-60$ & 23.3 & 54.4 & 2.4 \\
\hline \multirow{2}{*}{ Education Background } & SD (6 Th) & 50.0 & 6 & 0 \\
& SLTP (9 Th) & 26.6 & 9 & 0 \\
\hline \multirow{2}{*}{ Farming Experience (Year) } & SLTA (12 Th) & 23.3 & 12 & 0 \\
\hline \multirow{2}{*}{ The Number of Family Dependents (Orang) } & $1-20$ & 50.0 & 15.3 & 3.9 \\
& $21-40$ & 50.0 & 29.3 & 5.8 \\
\hline \multirow{2}{*}{ Land Area (Hectare) } & $2-3$ & 43.3 & 2.6 & 0.4 \\
& $4-5$ & 40.0 & 4.3 & 0.5 \\
& $>5$ & 16.6 & 6 & 0 \\
\hline
\end{tabular}

Source: Primary Data, processed in 2020.

Based on Table 1, it can be seen that in general, female farmers involved in rice farming in Pegayut village are mostly in the productive ages but tend to be middle-old ages. The lack of interest in the younger generation to participate in farming activities is one of the reasons for the difficulty of farmers in regenerating their workforce. As seen in the education variable, it can be said that the education of female agricultural workers in Pegayut Village is still low. It happens not only in Pegayut village but also in most Indonesia farmers in which they are mostly elementary and junior high school graduates. On the contrary, farmers in developed countries have a higher level of education even at master and doctoral levels.

By considering the characteristics of female farmers based on their farming experience, it can be seen that those who are involved in farming activities are experienced. It is proven by the mean score 15.3 which means most of the female family workers involved in managing rice farming in Pegayut Village have an average of 15 years of working experience. Next, seeing the characteristics of female farmers based on their family dependents, it can be concluded that most of them have at least 2-5 family dependents. Lastly, considering the characteristics of female farmers based on their own land area, data shows that in average, female farmers own and manage 1 hectare land area. Compared to the national average, that number is higher since the national data records that indonesian farmers in average only own and manage 0.25 hectare of land. However, if compared to farming in several developed countries, that number is much lower.

In doing rice farming using the family farming system, most of the farmers use family labors and the rest are non-family labors. Labors involved in rice farming are usually men, women, and children. In this research, the focus of the research is considering the role and supply of female labors in doing rice farming.

Based on data in Table 2, it shows that female farmers have a role play in all stages of rice farming. However, the biggest role in farming activities is planting and cultivation activities. It is supported by the result of the research conducted by Kewengian et al., (2019) which shows that farming activities are mostly done in planting and harvesting stages. The stages of planting and cultivation are considered as two important stages which can affect the success of farming in every growing season. Rice planting activity in Pegayut village is still done traditionally which takes bigger effort and longer time. Female farmers are usually responsible for planting rice seedlings. While men are responsible for arranging rice planting spacing. In general, this activity lasts for 3-7 days during the rice planting. The speed of this activity depends on the land area owned by the farmers. 
Table 2 - The Role of Female Labors in every Stage of Rice Farming

\begin{tabular}{|c|c|c|}
\hline $\begin{array}{l}\text { Activity } \\
\text { Stages }\end{array}$ & Job Descriptions & Working Time/Days \\
\hline $\begin{array}{l}\text { Rice } \\
\text { Seedling }\end{array}$ & $\begin{array}{l}\text { - } \quad \text { Doing rice seed submersion for } 3 \text { days. } \\
\text { Drying the submerged rice seeds until the seeds } \\
\text { begin to germinate. } \\
\text { - Undergoing supervision during the seedling } \\
\text { process }\end{array}$ & $\begin{array}{l}\text { Carried out for } 4-8 \text { hours/day (Performed } \\
\text { for 3-7 days in } 1 \text { planting period) }\end{array}$ \\
\hline Planting & $\begin{array}{l}\text { - Carrying out rice planting activity after the seeds } \\
\text { reach } 1 \text { month old since sowing. }\end{array}$ & $\begin{array}{l}\text { Carried out for 5-9 hours/day (Performed } \\
\text { for 3-7 day/ha land area) }\end{array}$ \\
\hline Cultivation & $\begin{array}{ll} & \text { Stitching dead plants } \\
\text { - } & \text { Weeding the wild plants }\end{array}$ & $\begin{array}{l}\text { Carried out for } 5-9 \text { hours/day (performed } \\
\text { during the planting period) }\end{array}$ \\
\hline Fertilization & $\begin{array}{l}\text { - Doing fertilization activity which is done when the } \\
\text { plants have reached } 3-4 \text { weeks old. } \\
\text { Carrying out another fertilization activity which is } \\
\text { done when the rice plants have reached } 6-8 \\
\text { weeks old. }\end{array}$ & $\begin{array}{l}\text { Carried out for } 5-8 \text { hours/day } \\
\text { (on average, } 1 \text { time fertilization process is } \\
\text { done for } 3 \text { days) }\end{array}$ \\
\hline Harvest & $\begin{array}{l}\text { - Helping the male workers to organize the } \\
\text { harvested rice. }\end{array}$ & $\begin{array}{l}\text { Carried out for } 5 \text { hours/day } \\
\text { (but usually the job is dominantly done by } \\
\text { male workers because the harvesting } \\
\text { process uses the combine) }\end{array}$ \\
\hline $\begin{array}{l}\text { Post- } \\
\text { Harvest }\end{array}$ & $\begin{array}{l}\text { - Carrying out post-harvest handling, starting from } \\
\text { grain drying, cooling, storing, packaging until } \\
\text { turning into ready-to-sell products. }\end{array}$ & $\begin{array}{l}\text { Carried out for } 5 \text { hours/day } \\
\text { (The duration depends on the weather) }\end{array}$ \\
\hline
\end{tabular}

Source: Primary Data, processed in 2020.

During the cultivation, female farmers play a lesser role compared to male farmers. Several activities which are commonly done by female farmers are replanting dead rice seedlings with the new one and clearing out weed plants. These activities are done almost every day during the growing season. While, male farmers have another role such as being responsible for controlling pests and diseases. However, in some cases, female farmers are also involved in controlling pests if male farmers are unable to do the activity.

In contrast, during the harvest stage, female farmers tend to play a lesser role than male farmers. This phenomenon happens since farmers in Pegayut Village have been applying modern technology by using combine harvester. In practice, the use of a combine hoster will be managed by male farmers. Therefore, harvesting will be more efficient since it can reduce the energy of farmers and harvest time. Harvesting using a combine hoster is usually done for one day only.

Labor supply is the number of effective workforces used in carrying out business activities. In this research, labor supply is calculated using HOK formula. Labor supply data of female farmers in every stage of managing rice farming in Pegayut Village can be seen in Table 3 below.

Table 3 - The Labor Supply of Female Farmers in Rice Farming at Pegayut Village

\begin{tabular}{lllc}
\hline $\begin{array}{l}\text { Rice Farming } \\
\text { Activities }\end{array}$ & $\begin{array}{l}\text { The Labor Supply of Female Farmers } \\
\text { (HOK/Year) }\end{array}$ & $\begin{array}{l}\text { The Labor Supply of Male Farmers } \\
\text { (HOK/Year) }\end{array}$ & \begin{tabular}{c} 
Total \\
\hline Rice Seedling
\end{tabular} \\
Planting & 6.31 & 2.01 & 5.32 \\
Cultivation & 5.73 & 3.73 & 10.00 \\
Fertilization & 3.51 & 3.96 & 9.69 \\
Harvest & 1.13 & 3.48 & 6.99 \\
\hline Total & 19.98 & 3.67 & 4.80 \\
\hline
\end{tabular}

Source: Primary Data, processed in 2020.

The result of the research in Table 3 shows that the total labor supply of rawa lebak rice farmers in Pegayut Village is $36,8 \mathrm{HOK} /$ year. The biggest labor supply is seen during the 
planting stage which is $6,27 /$ year or $63 \%$ and the cultivation stage which is $6,27 \mathrm{HOK} /$ year or $60 \%$. While, the lowest labor supply is seen during the harvest stage that is $1,13 \mathrm{HOK} /$ year or $23 \%$. It shows that female farmers are highly careful and patient which are needed during the planting and cultivation stages (clearing out weed plants and controlling pests and diseases). Other factors which affect the high labor supply during the planting and cultivation stages (clearing out weed plants and controlling pests and diseases) are the length of planting time which takes up to one week and cultivation which takes 3-5 days depending on the land area. The time length is different from rice seedling, fertilizing, and harvesting.

Based on the result of the research, rice seedling takes a shorter time while the fertilizing stage uses more energy of male than female farmers, and the lowest is during the harvest stage. It is contrast to the first hypothesis which states that the biggest percentage stage done by female farmers in rice farming is during the harvest time. This happens because during the harvest time, they use more male than female farmers and have been using combine harvester machine which shortens harvest time.

\section{CONCLUSION}

Female farmers have a role play in every stage of rice farming, especially during the planting time and cultivation. This happens since both stages are considered as important and determine the success of rice farming. Therefore, it needs patience in performing the job. On the contrary, the role of female farmers during the harvest time is lesser since they have been using modern technology such as the combine harvester machine so that the male a bigger role.

farmers

play

Having the same case with the role of female farmers, the biggest labor supply of female farmers are during the planting and cultivation stages. Compared to male farmers, labor supply of female farmers is not evenly distributed and tends to be supplied in several stages only.

\section{REFERENCES}

1. Badan Pusat Satatistik. 2019. Statistika Indonesia. Statistical Yearbook of Indonesia. ISSN 0126-2912.

2. Berdegué, J., Fuentealba, R. 2011. Latin America. The State of Smallholders in Agriculture. Peper Presented at the IFAD: Conference on New Directions for Smallhoder Agriculture.

3. Comitte on World Food Security. 2016. http://www.fao.org/cfs/home/blog/blogarticles/article/en/c/447783/

4. Garner, E., Campos, P. 2014. Identifying the "Family Farm" :an Informal Discussion of The Concepts and Definition. Food and Agricultural Organization (FAO) of The United Nations.

5. Han, Q. 2017. Family Farming and Rural Society Under the Shadow of Urbanization: A Case study of Agricultural Business Management in Chifeng, Inner Mongolia. SAGE Publication: Chinese Journal of Sociology, Vol. 3(3) 450-472.

6. Husodo, S. 2017. Artikel: Luas Iahan pertanian Indonesia masih minim. (online) https://nasional.kontan.co.id/news/luas-lahan-pertanian-indonesia-masih-

minim\#: :text=Dia\%20menjelaskan\%2C\%20luas\%20lahan\%20di,di\%20Indonesia\%20tid ak\%20bisa\%20berkembang.

7. Kewengian, T. Mandey, J. R.,, Waney, N. 2019. Curahan Tenaga Kerja pada Usahatani Padi di Desa Lowian Kecamatan Maesaan. Jurnal Agri-Sosio Ekonomi Unsrat, ISSN (p) 1907-4298. Vol. 5 (13) 397-406.

8. Khairati, R. dan Syahni, R. 2016. Respons Permintaan Pangan Terhadap Pertambahan Penduduk di Sumatera Barat. Jurnal Pembangunan Nagari. Vol. 1 (2).

9. Pakpahan. 2018. Artikel: HKTI: 200 Hektar di Kita untuk 1.000 Orang, di AS Satu Orang Mengelola

Pertanian

200

Hektar. 
https://ekonomi.kompas.com/read/2018/08/02/164200926/hkti--200-hektar-di-kita-untuk1.000-orang-di-as-satu-orang-mengelola.

10. Pujianto, E. 2008. Analisis Penyerapan dan Curahan Tenaga Kerja pada Usaha Peternakan Domba (Studi Kasus di Desa Cibunian Kecamatan Pamijahan dan Desa Cigudeg Kecamatan Cigudeg Kabupaten Bogor. Skripsi. Program Studi Sosial Ekonomi Peternakan Fakultas Peternakan. Institut Pertanian Bogor.

11. Ridwan, A., Lestari, R.D., Fanani, A. 2019. Contribution of Labor and Women Farmers Income in Poor Farmers Houshold Recipients PKH (Program Keluarga Harapan) at Kedungan Sub-District Bojonegoro Regency. Jurnal Ekonomi Pertanian dan Agribisnis (JEPA). Vol. 3 (1) 33-42.

12. Rohman, A. dan Maharani. 2017. Proyeksi kebutuhan konsumsi pangan Beras di Daerah Istimewa Yogyakarta. Journal of Sustainale Agriculture. 32 (1), 29-34.

13. Statista. 2019. Rice consumption worldwide in $2019 / 2020$, by country (in 1.000 metric tons). (Online:https://www.statista.com/statistics/255971/top-countries-based-on-riceconsumption-2012-2013/).

14. Sulistyo, S.R., Alfa, B.N. \& Subagyo, S., 2016 Modelling Indonesia's Rice Supply and Demand using System Dynamics In: IEE International Conference on Industrial Engineering and Engineering Management. Hh. 415-419.

15. Verma, D. K., Srivastav, P.P., 2020. Bioactive compounds of Rice (Oryza Sativa L.): Review on Paradigm and Its Potential benefits in Human Health. Elsevier Publication: Trends in Food Science \& Technology. Vol. 97 355-365.

16. Wardani, C., Jamhari, Hardyastuti, S., Suryantini, A. 2019. Kinerja Ketahanan Beras di Indonesia: Komparasi Jawa dan Luar Jawa Periode 2005-2017. Jurnal Ketahanan Nasional: Universitas Gadjah Mada. Vol. 25 (1) 107-130. 